\title{
Response of avian nectarivores to the flowering of Aloe marlothii: a nectar oasis during dry South African winters
}

\author{
Craig T. Symes ${ }^{1}$, Susan W. Nicolson ${ }^{1}$ and Andrew E. McKechnie ${ }^{2}$
}

(1) Department of Zoology and Entomology, University of Pretoria, Pretoria, 0002, South Africa

(2) School of Animal, Plant and Environmental Sciences, University of the Witwatersrand, Private Bag 3, Wits, 2050, South Africa

\author{
Craig T. Symes \\ Email: craig.symes@zoology.up.ac.za
}

\section{Abstract}

In southern Africa, Aloe marlothii flowers during the dry winter season and offers copious dilute nectar to a variety of birds. Avian abundance and community composition were monitored at an A. marlothii forest at Suikerbosrand Nature Reserve, South Africa. Sampling occurred during two summer months (February-March) when no flowers were present, and six months (May-October) that spanned the winter flowering. We hypothesized that an influx of occasional nectarivores to the A. marlothii forest during flowering would lead to significant changes in the avian community. Overall bird abundance increased 2-3 fold at the peak of nectar availability (August). We recorded 38 bird species, of 83 species detected during transects, feeding on A. marlothii nectar; this diverse assemblage of birds belonged to 19 families, including Lybiidae, Coliidae, Pycnonotidae, Sylviidae, Cisticolidae, Muscicapidae, Sturnidae, Ploceidae and Fringillidae. Surprisingly, only two species of sunbird (Nectariniidae) were observed feeding on A. marlothii nectar, and both occurred in low abundance. We predicted that competition for nectar resources would be high, but few aggressive inter- and intraspecific interactions occurred between birds while feeding on inflorescences. During peak flowering, insect feeders (insectivores, omnivores, nectarivores) fed on nectar during the cold morning when insect activity was low, whilst non-insect feeders (frugivores and granivores) fed on nectar in the middle of the day. Our study highlights the importance of $A$. marlothii nectar as a seasonal food and water source for a diverse assemblage of occasional nectarivores. 


\section{Introduction}

The structure and composition of avian communities change in space and time with the availability of food resources. Variation tends to be most pronounced among consumers that feed on patchy and ephemeral food resources such as nectar and fruit (Fleming 1992). The responses of nectarivores to variation in food availability are well documented, with increases in abundance and diversity being correlated with increased nectar availability (e.g., Brown and Hopkins 1996; Franklin and Noske 1999; Cotton 2006). In South Africa, sunbirds (Nectariniidae) respond to patchy nectar resources, e.g., Protea and Leonotis spp. (Skead 1967; Tree 1990; Craig and Simon 1991; Craig and Hulley 1994; Symes et al. 2001), and Gurney's Sugarbirds Promerops gurneyi are recorded using seasonally available nectar sources (de Swardt 1991; de Swardt and Louw 1994). Cape Sugarbirds $P$. cafer are also known to appear in greater numbers at flowering Protea spp., and movements up to $160 \mathrm{~km}$ within their restricted range have been recorded (Fraser et al. 1989; Fraser and McMahon 1992).

While the examples above concern specialist nectarivores, occasional nectarivory is recorded worldwide in numerous bird families, with a predominance on the southern continents (Maclean 1990). In the Neotropics, honeycreepers (Coerebidae), the New World blackbirds (Icteridae), tanagers (Thraupidae) and finches (Fringillidae) are common nectar feeders (Stiles 1981; Gryj et al. 1990). In Australasia, a host of insectivores feed on nectar, with the number of species in monsoonal Australia given as 29 (from 15 families) (Paton 1986; Franklin 1999). Numerous birds have been recorded foraging on the nectar of Erythrina species, including generalist passerines (Steiner 1979; Raju and Rao 2004), parrots (Psittacidae) (Cotton 2001) and hummingbirds (Trochilidae) (Mendoça and dos Anjos 2006). In South Africa, at least 73 bird species in 24 families were recorded feeding on 14 Aloe species and 8 other flowering plants and trees, although this list is far from exhaustive (Oatley and Skead 1972). Occasional nectarfeeding is therefore more common than previously believed, and the 1,600 birds quoted by Peterson et al. (1968) may be no exaggeration.

In many southern African ecosystems, aloes (Aloe spp.) represent an important source of nectar for birds during dry winter months (Oatley 1964; Skead 1967; Oatley and Skead 1972). Aloe marlothii occurs in the northern and north-eastern summer rainfall regions of South Africa where winters are dry with warm days $\left(>20^{\circ} \mathrm{C}\right)$ and cold nights $\left(\mathrm{c} .0^{\circ} \mathrm{C}\right)$. This species reaches a maximum height of c. $8 \mathrm{~m}$ and produces a single inflorescence with up to 25 racemes in a flowering season, although not all plants flower each year (Symes and Nicolson, unpublished data). This study was conducted at Suikerbosrand Nature Reserve during 8 months that included the flowering period of $A$. marlothii. We investigated seasonal variation of the avian community, hypothesizing that bird abundance and diversity would increase with the availability of $A$. marlothii nectar. We predicted that the seasonal response would be most pronounced in true nectarivores, such as sunbirds (Nectariniidae). Occasional nectarivore species were also expected to increase in abundance during the flowering season, in proportion to their degree of nectarivory. We also expected competition for nectar during flowering, and investigated 
feeding behavior of birds throughout the day in order to identify temporal niche partitioning.

\section{Methods}

Our study site was an A. marlothii "forest" in the western part of Suikerbosrand Nature Reserve, $60 \mathrm{~km}$ south-east of Johannesburg, where large numbers of $A$. marlothii plants occur mainly on rocky north-facing slopes. Data were collected during a 6-month period (May-October 2006) that spanned the entire 2006 winter flowering event, and during the summer non-flowering season (February-March 2006). Additional feeding and behavioral observations were also recorded during the 2005 flowering season (JulySeptember).

\section{Diversity and abundance censusing}

The avian community was censused in the western portion $\left(26^{\circ} 31^{\prime} 50^{\prime \prime} \mathrm{S}, 28^{\circ} 10^{\prime} 07^{\prime \prime} \mathrm{E}\right.$, c.1,600-1,700 m a.s.1.) of the A. marlothii "forest". Each census session involved a combination of point counts and transect sampling along a disused vehicle track. Following an initial 10-min point count, an observer (C.T.S.) walked along the $300-\mathrm{m}$ transect route for $20 \mathrm{~min}$. Thereafter, a second $10-\mathrm{min}$ point count was conducted at the end of the transect route. After a delay of $10 \mathrm{~min}$, this procedure was then repeated in the reverse direction, so that each session comprised four 10-min point counts and two 20min transects (i.e., a total of $80 \mathrm{~min})$. Sampling took place in the morning (06001000 hours), at midday (1000-1400 hours), or in the afternoon (1400-1800 hours), with only one session being conducted during each period in a day. Two sessions were conducted for each period in a month, and bird census sampling was completed over 35 days. Total census time each month was thus $8 \mathrm{~h}$.

During each census period, all birds detected visually or by sound in the aloe "forest" were recorded. Resightings during each point count and transect were not included. We also recorded all instances of feeding behavior on aloes during the flowering season (i.e., probing flowers and feeding on buds, open flowers or seed pods). Birds feeding on nectar out of transect periods were also recorded (including pilot transects walked in 2005). Each species was classified into a broad feeding guild, i.e., frugivore, granivore, insectivore, nectarivore, omnivore, and also as a seasonal migrant or not, following Maclean (1993) and Hockey et al. (2005).

Some bird species occur in greater numbers than others and we calculated an abundance index for each species that accounted for inter-species abundance variations. This was the number of individuals of a species recorded each month as a proportion of the total number of individuals recorded for that species.

\section{Pollen loads and visitation rates}

To confirm the presence of $A$. marlothii pollen on particular species, we trapped birds using mist nets at two sites, $250 \mathrm{~m}$ apart, along a portion of the disused vehicle track in the aloe forest. Six nets $(12 \times 2.4 \mathrm{~m}, 4$ shelf, $16 \mathrm{~mm}$ mesh $210 \mathrm{~d} / 1$ ply nets $)$ were erected $(0.6-3.0 \mathrm{~m})$ on aluminium poles $(3 \mathrm{~m})$ along a single stretch during each trapping session. 
Bird capture took place throughout the day (59.6 h during 9 days). Each bird was ringed and inspected visually for pollen deposited on the bill and feathers of the facial region. During flowering months, pollen swabs were collected from representatives of all species on which pollen was not immediately visible, using a piece of transparent adhesive tape that was dabbed on the bill, frons and throat region and then placed on a slide. The slide was later scanned for pollen under a light microscope at $10 \times$ magnification.

To determine visitation rates of birds to flowering A. marlothii, we selected 3-8 aloes of varying height within $15 \mathrm{~m}$ of a randomly chosen observation point. For each visitor, the time and species was recorded, whether or not it fed, and any interactions with other birds. Observations lasted for 10-45 min at each station, with sampling periods throughout the day during peak flowering in late August. For each species, we calculated the proportion of individuals that were observed feeding at different times of the day.

\section{Results}

\section{Seasonal variation in community composition}

We observed 83 species during censuses (Appendix), with both diversity and abundance peaking in August when nectar availability was greatest (Symes and Nicolson, unpublished data; Table 1, Fig. 1). Eight seasonal migrant species were present during summer and only one migrant species was present during the flowering period in August. During May-October, abundance was higher during the morning and afternoon sampling periods than at midday, whereas this pattern was not evident during February or March (Fig. 1). During flowering (August-September) the number of nectar feeding observations for each species was correlated with the overall abundance of each species (Spearman's $R=0.836, P<0.05$ ).

Table 1 Number of bird species and individuals detected during transects (total and excluding migrants, $n=9$ ) during February-March and May-October 2006

\begin{tabular}{|l|l|l|l|l||}
\hline \multirow{2}{*}{ Month } & \multicolumn{2}{|l|}{ Number of species } & \multicolumn{2}{|l|}{ Number of individuals } \\
\hline & $\begin{array}{l}\text { Migrants } \\
\text { included }\end{array}$ & $\begin{array}{l}\text { Migrants } \\
\text { excluded }\end{array}$ & $\begin{array}{l}\text { Migrants } \\
\text { included }\end{array}$ & $\begin{array}{l}\text { Migrants } \\
\text { excluded }\end{array}$ \\
\hline February & 52 & 46 & 954 & 771 \\
\hline March & 48 & 44 & 980 & 802 \\
\hline May & 48 & 48 & 892 & 892 \\
\hline June & 42 & 42 & 694 & 694 \\
\hline July & 45 & 44 & 1,074 & 1,065 \\
\hline August & $\mathbf{5 3}$ & $\mathbf{5 2}$ & $\mathbf{1 , 7 4 6}$ & $\mathbf{1 , 7 4 6}$ \\
\hline September & 47 & 45 & 745 & 727 \\
\hline October & 50 & 46 & 632 & 579 \\
\hline $\begin{array}{l}\text { Cumulative } \\
\text { total }\end{array}$ & 89 & 83 & & \\
\hline
\end{tabular}


Peak flowering month italicized. Totals also include unidentified species, e.g., francolin, cisticola, weaver, waxbill or canary species (see "Appendix")

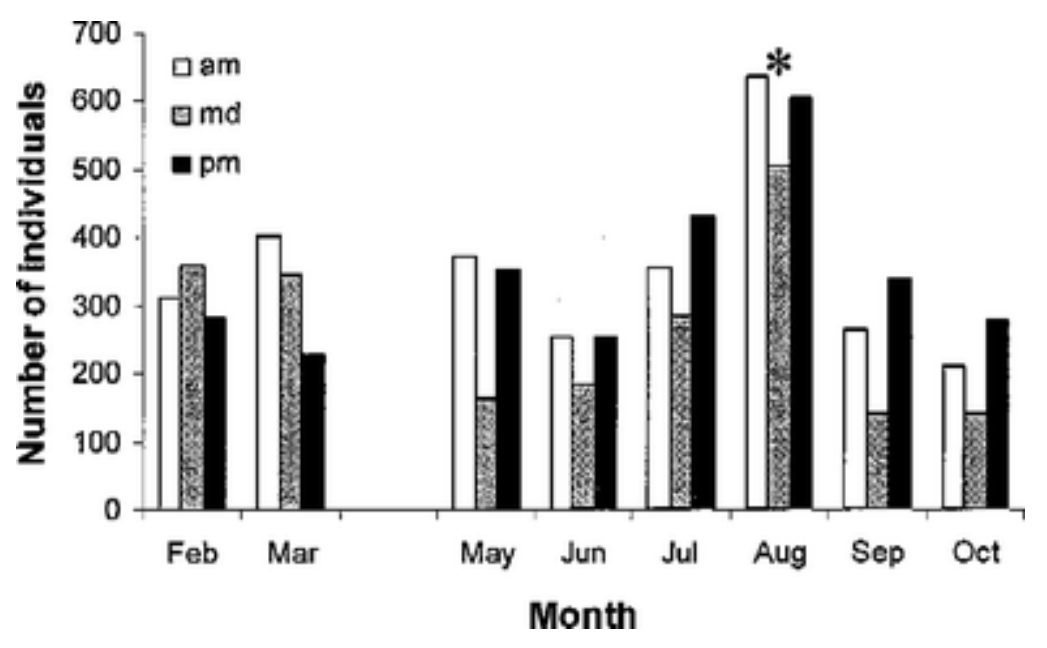

Fig. 1 Monthly bird abundance in an Aloe marlothii forest at Suikerbosrand Nature Reserve. Sampling took place in the morning (am 0600-1000 hours), midday ( $m d 1000$ 1400 hours) or afternoon ( $p m$ 1400-1800 hours). An asterisk indicates A. marlothii peak flowering

When we accounted for inter-species differences in abundance, there was no significant difference in abundance between months for all birds detected in the aloe forest during transects (Kruskal-Wallis, $P=0.07$ ) (Fig. 2). However, when nectar feeders were treated separately there was a significant difference in abundance between months (KruskalWallis, $P=0.002$; Fig. 2).

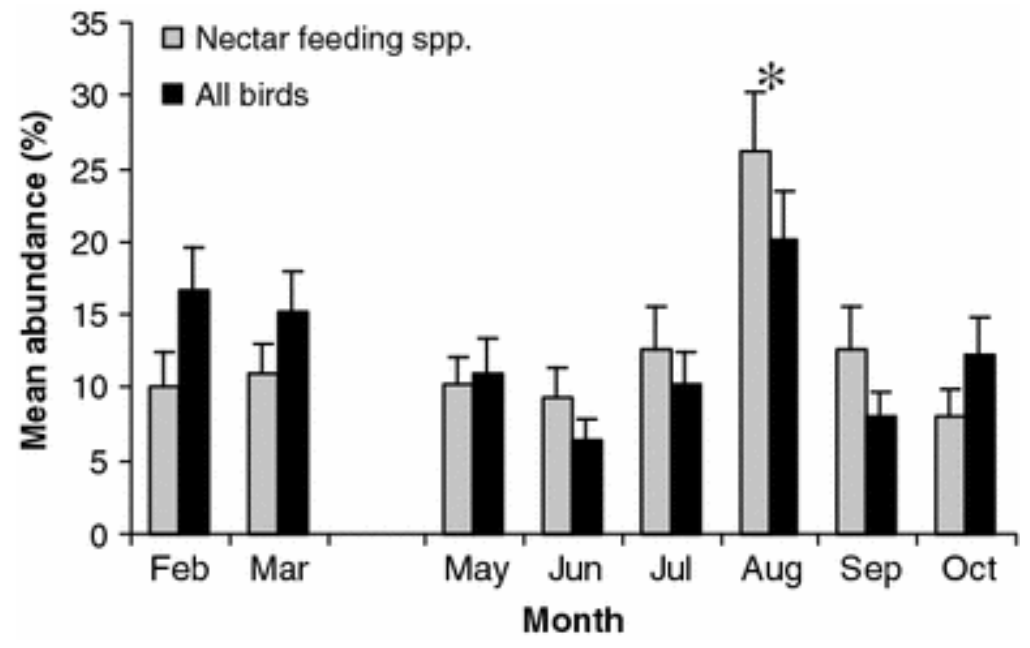

Fig. 2 Mean abundance $(\% \pm \mathrm{SE})$ of birds recorded each month in the aloe forest at Suikerbosrand Nature Reserve. Monthly abundance for each species calculated as a 
percentage of total abundance for that species. All birds all species detected during transects; Nectar feeders only species recorded as Aloe marlothii nectar feeders. An asterisk indicates $A$. marlothii peak flowering

\section{Floral visitors}

During transects, 21 species were observed feeding on nectar. Another three species were recorded feeding on nectar out of transect periods and an additional seven species were seen feeding on nectar in 2005 . Of 30 species caught, individuals of 26 species were found to have pollen on the facial area (15 with visible pollen, and 11 species with pollen detected from swabs). Seven species were classed as nectarivores from pollen swabs alone (Appendix); no pollen from other plant species was visible on the slides. A total of 38 species representing 19 families were thus recorded feeding on A. marlothii nectar during the study (Appendix). An additional four species known to feed on A. marlothii nectar, but not recorded doing so during the study, are also included in the Appendix (Oatley 1964; Oatley and Skead 1972). This gives a total of 42 occasional nectar feeders at the Suikerbosrand aloe "forest", representing $59.2 \%$ of the bird community present at the site in winter (migrants and transients excluded).

The proportion of individuals of various feeding guilds (frugivores, granivores, insectivores, nectarivores and omnivores) feeding on $A$. marlothii nectar varied significantly among sampling periods (Kruskal-Wallis, $P<0.05$; Fig. 3). Overall visitation rates to aloes were highest in the morning for insectivores, nectarivores and omnivores (all insect eaters) but higher at midday for frugivores and granivores (Fig. 3). For all species combined there was a general decrease in feeding through the day.

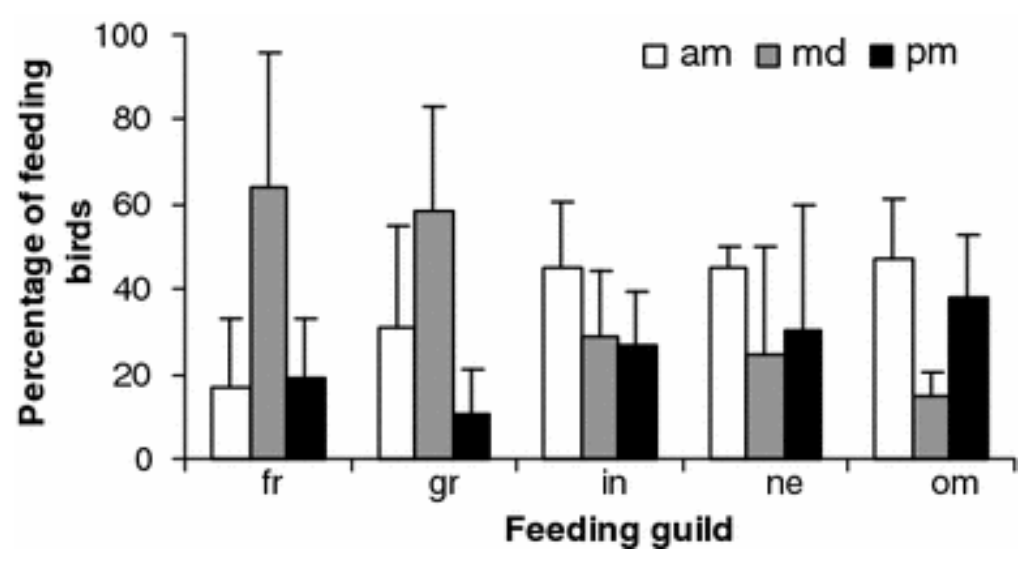

Fig. 3 Percentage of individuals belonging to various feeding guilds that were observed feeding on Aloe marlothii nectar at different time periods in a day at Suikerbosrand Nature Reserve (feeding guilds: fr frugivore, gr granivore, in insectivore, ne nectarivore, om omnivore). Values given as mean \pm SE. Refer to Fig. 1 for times

The following seven species accounted for $86.4 \%$ of individuals seen feeding on nectar: African Red-eyed Bulbul Pycnonotus nigricans (36.6\%), Cape Weaver Ploceus capensis (18.6\%), Cape White-eye Zosterops capensis (9.0\%), Red-faced Mousebird Urocolius 
indicus (7.9\%), Southern Masked Weaver Ploceus velatus (5.7\%), Fiscal Flycatcher Sigelus silens (4.3\%) and Streaky-headed Seedeater Serinus gularis (4.3\%). Three species (African Red-eyed Bulbul, Chestnut-vented Tit-babbler Parisoma subcaeruleum and Streaky-headed Seedeater) were observed feeding on A. marlothii fruit, and ten species were observed drinking water from A. marlothii leaves (Laughing Dove Streptopelia senegalensis, Fiscal Flycatcher, Black-throated Canary Serinus atrogularis, Black-collared Barbet Lybius torquatus, Common Scimitarbill Rhinopomastus cyanomelas, Ashy Tit Parus cinerascens, African Red-eyed Bulbul, Streaky-headed Seedeater, Cape Bunting Emberiza capensis and Black-faced Waxbill Estrilda erythronotos). A further two species were observed probing unopened flowers (unidentified canary species and Black-chested Prinia Prinia flavicans).

We did not observe any aggressive inter- or intra-specific interactions during sampling periods, but did observe male malachite sunbirds Nectarinia famosa chasing a female sunbird, an Ashy Tit, a Cape White-eye and a Laughing Dove at the study site during 2005 and 2006. Several bird species were often observed feeding on the same inflorescence, with larger species tending to displace smaller species.

\section{Discussion}

\section{Nectar-feeding at a mass flowering event}

The occurrence of numerous bird species, with half observed feeding on nectar at the mass flowering of $A$. marlothii, indicates that nectar is an important source of food and/or water for many occasional nectarivores during dry winters. The abundance of nectarfeeding bird species increased significantly when aloes flowered, with some species being present only during flowering months; e.g., Wattled Starling Creatophora cinerea, Red-winged Starling Onychognathus morio and Malachite Sunbird, which are known to migrate locally while tracking food resources (Skead 1967; Craig 1996; Fraser 1997; Symes et al. 2001). Also, the presence of Fairy Flycatcher Stenostira scita, Red-billed Oxpecker Buphagus erythrorhynchus, Cut-throat Finch Amadina fasciata and Goldenbreasted Bunting Emberiza flaviventris only when aloes were in flower suggests that their arrival in the area was as occasional nectarivores.

Surprisingly, true nectarivores (sunbirds) did not respond significantly to the seasonal availability of $A$. marlothii nectar, possibly because the nectar concentration is too low to be attractive to specialist nectar feeders (Johnson and Nicolson, unpublished data). Moreover, populations of sunbirds may be equally distributed throughout the range of flowering A. marlothii, resulting in more dispersed populations. Despite this, the occurrence of sunbirds in high densities at other patchy and transitory flowering events in South Africa is well recorded (see Harrison et al. 1997).

Other aloe species are likely to drive seasonal changes in avian communities like those we observed in A. marlothii. Aloe ferox, for instance, occupies a similar ecological niche and also offers large amounts of nectar to visitors during dry winter months when few other plants are flowering (Reynolds 1969; van Wyk and Smith 2003). The vertical 
racemes of $A$. ferox and the horizontal to slanting racemes of $A$. marlothii both offer copious volumes of dilute nectar $(180 \mu \mathrm{l}, 12.5 \% \mathrm{w} / \mathrm{w}$ and $250 \mu 1,12 \% \mathrm{w} / \mathrm{w}$, respectively) (Hoffman 1988; Symes and Nicolson, unpublished data). Oatley and Skead (1972) recorded 28 and 26 bird species visiting $A$. marlothii and A. ferox, respectively. In both plants, the inflorescences are robust enough to support birds as large as Grey Go-awaybirds Corythaixoides concolor and columbids ( $>250$ g) (Oatley and Skead 1972; Symes and Nicolson, unpublished data). At least 360 Aloe species occur throughout the Afrotropical region (Jeppe 1969; Reynolds 1969; Glen and Hardy 2000). Flowering occurs at different times of the year, although in southern Africa there is a dominance of winter flowering aloes (Jeppe 1969; Reynolds 1969). Aloe nectar provided during seasonal mass flowering events is an important food and water source for a wide range of bird species (Oatley 1964; Skead 1967; Oatley and Skead 1972; Botes 2007).

\section{A distinct bird community during flowering}

In addition to an increase in avian diversity during the flowering period (up to 20\%), there was a 2-3 fold increase in overall bird abundance. This occurred despite the absence of seasonal migrants, which were only present at the aloe forest in summer months when there was no nectar. Our data thus support the hypothesis that the availability of nectar in the $A$. marlothii forest is associated with significant changes in avian community diversity and abundance.

Species like African Red-eyed Bulbul, Cape Weaver, Cape White-eye, Red-faced Mousebird, Southern Masked Weaver, Fiscal Flycatcher and Streaky-headed Seedeater that accounted for most feeding observations were the species that increased in abundance during flowering. Chestnut-vented Titbabbler and Black-chested Prinia also increased in abundance during flowering, but because they were less common, were seen feeding less often. The importance of nectar for these species is supported by stable carbon isotope analysis, which indicates that nectar contributes up to $15 \%$ of their dietary carbon intake during the aloe flowering period (Symes, Woodborne, McKechnie and Nicolson, unpublished data).

The seasonal variation in avian diversity and abundance associated with nectar availability is similar to that observed in other systems. Woinarski and Tidemann (1991), for instance, identified distinct bird communities between the dry season, transitional months and wet season months in a Northern Australian woodland bird community. They also found that nectarivore density was strongly correlated with flower availability (Woinarski and Tidemann 1991). In monsoonal Australia, opportunistic nectarivory amongst birds occurs predictably at mass flowering events and during the cool dry season (Franklin 1999). In Perth (western Australia), a guild of honeyeaters (five species) responded to peaks in nectar production of a single plant species, Banksia menziesii (Proteaceae), with significantly more birds being observed during winter flowering (Ramsey 1989), and in a lowland Amazonian rainforest, seasonal fluctuations in resource abundance were closely correlated with variation in hummingbird species richness ( 17 species) and abundance (Cotton 2006). 


\section{Niche partitioning and defending nectar resources}

Insectivores are more likely than other guilds to practice occasional nectarivory (Paton 1986). A greater proportion of insect-eating birds (i.e., insectivores, omnivores, nectarivores) fed on nectar of $A$. marlothii in the morning. Frugivores and granivores (non-insect eaters) fed later, and although for each guild the differences are not statistically significant, the trend indicates some degree of temporal niche partitioning between insect and non-insect eaters in a day. Timewell and MacNally (2004) showed similar patterns for a guild of honeyeaters (ten species) feeding on winter flowering Eucalyptus tricarpa; the birds progressed from an almost exclusive nectar diet in the morning to increased insectivory later in the day. During cold mornings nectar is abundant but birds relying on insects are likely to experience difficulty finding food. Peak flowering of A. marlothii occurs at a time of low insect numbers, which possibly accentuates this separation (Symes and Nicolson, unpublished data). Different temporal feeding patterns between insect and non-insect eating guilds in a day, together with an abundant supply of nectar, lead to reduced competition for nectar and possible inter and intra-species aggressiveness.

There were more flowers available in the aloe forest than could be probed by birds; a flowering aloe produced, on average, at least $860 \mathrm{ml}$ of nectar (not accounting for destroyed flowers or replenished nectar in emptied flowers) (Symes and Nicolson, unpublished data). This mass flowering event is similar to the Jarrah forest site in Western Australia where the production of nectar of six plant species (e.g., Jarrah Eucalyptus marginata) between October and December could have supported more honeyeaters than were actually present (Collins and Newland 1986). In the aloe forest, few inter- and intra-specific aggressive interactions were observed; in contrast to those at other nectar sources frequented by sunbirds, honeyeaters and hummingbirds (e.g., Gill and Wolf 1975; Frost and Frost 1980; Ford 1981; Armstrong 1991; Cotton 1998). Temporal resource partitioning in nectarivores feeding at an Agave marmorata nectar oasis has been interpreted as a way to reduce risk of injury (Ornelas et al 2002). At our study site, temporal feeding patterns in a day were probably caused by responses to daily insect activity, rather than competition for nectar resources.

\section{Concluding remarks}

Community changes at our study site contrast with other studies in that the birds that arrived in the area in response to increased nectar availability were almost all occasional or generalist nectarivores rather than specialist nectarivores such as sunbirds. This observation may be related to nectar preferences: whereas specialist avian nectarivores tend to prefer nectars of relatively low volume (c.10-30 $\mu$ l) and high concentration (c.15$25 \% \mathrm{w} / \mathrm{w})$, generalist nectarivores prefer nectar of large volumes (c.40-100 $\mu \mathrm{l})$ and low concentrations (c.8-12\%) (Johnson and Nicolson, unpublished data). A second, and not mutually exclusive, possibility is that these patterns reflect variation in avian nectarivore species richness at a global scale: whereas the Neotropical (324 hummingbird species) and Australasian (159 honeyeaters) regions have large, speciose nectarivore radiations, the Afrotropical (78 sunbirds and 2 sugarbirds) and Indomalayan (39 sunbirds and 10 honeyeaters) regions do not (Maclean 1990). 


\section{Zusammenfassung}

Reaktion von nektarivoren Vögeln auf das Blühen von Aloe marlothii: Eine Nektaroase während trockener südafrikanischer Winter

In Südafrika blüht Aloe marlothii während der trockenen Wintermonate und bietet reichlich Nektar für eine Vielzahl von Vögeln. Abundanz und Zusammensetzung der Vogelgesellschaften wurde untersucht in einem A. marlothii Wald im Suikerbosrand Nature Reserve in Südafrika. Die Datenaufnahme fand in zwei Sommermonaten (Februar-März) statt, wenn keine Blüten vorhanden sind und während sechs Monaten im Winter (Mai-Oktober) zur Zeit der Winterblüte. Unsere Hypothese war, dass ein Zustrom von zeitweilig nektarivoren Vögeln in den A. marlothii Wald während der Blüte zu signifikanten Veränderungen in der Vogelgesellschaft führen würde. Die Abundanz von Vögeln stieg auf das 2- bis 3-fache zu Spitzenzeiten der Verfügbarkeit von Nektar im August. 38 der insgesamt 83 Vogelarten bei den Transektenzählungen nutzen $A$. marlothii Nektar. Diese Vögel gehörten 19 verschiedenen Familien an, unter anderem Lybiidae, Coliidae, Pycnonotidae, Sylviidae, Cisticolidae, Muscicapidae, Sturnidae, Ploceidae und Fringillidae. Erstaunlicherweise wurden nur zwei Arten von Nektarvögeln (Nectariniidae) bei der Nahrungsaufnahme an A. marlothii beobachtet, und beide waren nicht häufig. Wir nahmen an, dass der Wettbewerb um Nektar-Ressourcen hoch sein sollte, doch beobachteten wir nur wenige aggressive inter- und intraspezifische Interaktionen zwischen Vögeln bei der Nahrungsaufnahme an den Blüten. Während der Hauptzeit der Blüte gingen Vögel, die Insekten fressen (Insektivore, Omnivore und Nektarivore) während des kalten Morgens an die Blüten, wenn die Aktivität der Insekten niedrig war. Vögel, die keine Insekten fressen (Frugivore und Granivore) gingen dagegen am Mittag an die Blüten. Unsere Studie unterstreicht die Wichtigkeit von A. marlothii Nektar als eine saisonale Nahrungs- und Wasserquelle für verschiedenste zeitweilige nektarivore Vogelarten.

\section{Appendix}

Table 2 Bird species $(n=85)$ recorded during transects (February-March, May-October) in the Aloe marlothii forest, western Suikerbosrand Nature Reserve

\begin{tabular}{|c|c|c|c|c|c|c|c|c|c|c|c|}
\hline Species & Nectar & Status & Feb & Mar & May & Jun & Jul & Aug & Sep & Oct & Total \\
\hline \multicolumn{12}{|l|}{ Phasianidae } \\
\hline $\begin{array}{l}\text { Swainson's Spurfowl } \\
\text { Pternistis swainsonii }\end{array}$ & - & - & 4 & 3 & 17 & 5 & 23 & 0 & 1 & 1 & 54 \\
\hline \multicolumn{12}{|l|}{ Numididae } \\
\hline $\begin{array}{l}\text { Helmeted Guineafowl } \\
\text { Numida meleagris }\end{array}$ & - & - & 0 & 1 & 0 & - & - & - & - & 1 & 2 \\
\hline Anati & & & & & & & & & & & \\
\hline
\end{tabular}




\begin{tabular}{|c|c|c|c|c|c|c|c|c|c|c|c|}
\hline Species & Nectar & Status & Feb & Mar & May & Jun & Jul & Aug & Sep & Oct & Total \\
\hline $\begin{array}{l}\text { Egyptian Goose } \\
\text { Alopochen aegyptiaca }\end{array}$ & - & $\operatorname{tr}$ & - & - & - & - & 2 & - & - & - & 2 \\
\hline \begin{tabular}{|l|} 
Spur-winged Goose \\
Plectropterus gambensis
\end{tabular} & - & $\operatorname{tr}$ & - & - & - & - & - & - & - & 1 & 1 \\
\hline \multicolumn{12}{|l|}{ Indicatoridae } \\
\hline $\begin{array}{l}\text { Greater Honeyguide } \\
\text { Indicator indicator }\end{array}$ & - & - & - & - & - & - & - & - & - & 0 & 0 \\
\hline $\begin{array}{l}\text { Lesser Honeyguide } \\
\text { Indicator minor }\end{array}$ & $\mathrm{s}, 2$ & - & - & 1 & - & - & - & 1 & - & - & 2 \\
\hline \multicolumn{12}{|l|}{ Picidae } \\
\hline $\begin{array}{l}\text { Red-throated Wryneck } \\
\text { Jynx ruficollis }\end{array}$ & - & - & 1 & 2 & 0 & 0 & 0 & 1 & 0 & 2 & 6 \\
\hline $\begin{array}{l}\text { Cardinal Woodpecker } \\
\text { Dendropicos fuscescens }\end{array}$ & s & - & 0 & 0 & 2 & 0 & 4 & 0 & 0 & 4 & 10 \\
\hline \multicolumn{12}{|l|}{ Lybiidae } \\
\hline \begin{tabular}{|l} 
Acacia Pied Barbet \\
Tricholaema leucomelas
\end{tabular} & $\mathrm{t}, \mathrm{p}, 1,2$ & - & 11 & 12 & 7 & 6 & 4 & 9 & 2 & 12 & 63 \\
\hline $\begin{array}{l}\text { Black-collared Barbet } \\
\text { Lybius torquatus }\end{array}$ & $\mathrm{p}, 1,2$ & - & 0 & 3 & 0 & 1 & 7 & 0 & 1 & 0 & 12 \\
\hline $\begin{array}{l}\text { Crested Barbet } \\
\text { Trachyphonus vaillantii }\end{array}$ & $\mathrm{t}, 2$ & - & 2 & 16 & 4 & 4 & 0 & 6 & 5 & 1 & 38 \\
\hline \multicolumn{12}{|l|}{ Upupidae } \\
\hline $\begin{array}{l}\text { African Hoopoe Upupa } \\
\text { africana }\end{array}$ & - & mig & - & 1 & - & - & - & - & - & - & 1 \\
\hline \multicolumn{12}{|l|}{ Phoeniculidae } \\
\hline $\begin{array}{l}\text { Green Wood-Hoopoe } \\
\text { Phoeniculus purpureus }\end{array}$ & - & - & - & - & - & - & - & - & - & 1 & 1 \\
\hline \multicolumn{12}{|l|}{ Rhinopomastidae } \\
\hline $\begin{array}{l}\text { Common Scimitarbill } \\
\text { Rhinopomastus } \\
\text { cyanomelas }\end{array}$ & $t, 1,2$ & - & 4 & 3 & 2 & 6 & 2 & 6 & 9 & 2 & 34 \\
\hline \multicolumn{12}{|l|}{ Coliidae } \\
\hline $\begin{array}{l}\text { Speckled Mousebird } \\
\text { Colius striatus }\end{array}$ & $\mathrm{t}, \mathrm{p}, 1,2$ & - & 0 & - & - & 1 & 0 & 6 & - & - & 7 \\
\hline $\begin{array}{l}\text { Red-faced Mousebird } \\
\text { Urocolius indicus }\end{array}$ & $\mathrm{t}, \mathrm{p}, 1,2$ & - & 0 & 31 & 96 & 0 & 5 & 166 & 43 & 13 & 354 \\
\hline Cuculidae & & & & & & & & & & & \\
\hline
\end{tabular}




\begin{tabular}{|c|c|c|c|c|c|c|c|c|c|c|c|}
\hline Species & Nectar & Status & Feb & Mar & May & Jun & Jul & Aug & Sep & Oct & Total \\
\hline \begin{tabular}{|l} 
Diderick Cuckoo \\
Chrysococcyx caprius
\end{tabular} & - & mig & 1 & - & - & - & - & - & - & - & 1 \\
\hline \multicolumn{12}{|l|}{ Apodidae } \\
\hline Little Swift Apus affinis & - & tr & 2 & - & - & - & - & - & 10 & 6 & 18 \\
\hline $\begin{array}{l}\text { White-rumped Swift } \\
\text { Apus caffer }\end{array}$ & - & mig & 29 & - & - & - & 9 & - & 3 & 2 & 43 \\
\hline \multicolumn{12}{|l|}{ Columbidae } \\
\hline $\begin{array}{l}\text { Rock Dove Columba } \\
\text { livia }\end{array}$ & - & $\operatorname{tr}$ & - & - & - & - & 7 & 1 & - & - & 8 \\
\hline \begin{tabular}{|l} 
Speckled Pigeon \\
Columba guinea
\end{tabular} & - & $\operatorname{tr}$ & 59 & 1 & 2 & 2 & 5 & - & - & - & 70 \\
\hline $\begin{array}{l}\text { Laughing Dove } \\
\text { Streptopelia senegalensis }\end{array}$ & $\mathrm{s}, 1,2$ & - & 327 & 323 & 380 & 424 & 736 & 561 & 310 & 191 & 3,252 \\
\hline $\begin{array}{l}\text { Cape Turtle-Dove } \\
\text { Streptopelia capicola }\end{array}$ & 1 & - & - & - & 0 & 4 & 0 & 1 & 0 & - & 5 \\
\hline $\begin{array}{l}\text { Red-eyed Dove } \\
\text { Streptopelia semitorquata }\end{array}$ & - & - & - & - & 1 & - & - & - & - & - & 1 \\
\hline \multicolumn{12}{|l|}{ Charadriidae } \\
\hline $\begin{array}{l}\text { Crowned Lapwing } \\
\text { Vanellus coronatus }\end{array}$ & - & $\operatorname{tr}$ & - & - & - & - & - & - & 0 & - & 0 \\
\hline \multicolumn{12}{|l|}{ Laridae } \\
\hline $\begin{array}{l}\text { Grey-headed Gull Larus } \\
\text { cirrocephalus }\end{array}$ & - & $\operatorname{tr}$ & - & - & 2 & - & - & - & - & - & 2 \\
\hline \multicolumn{12}{|l|}{ Accipitridae } \\
\hline $\begin{array}{l}\text { Black-shouldered Kite } \\
\text { Elanus caeruleus }\end{array}$ & - & - & 3 & 2 & - & - & - & 1 & - & 2 & 8 \\
\hline $\begin{array}{l}\text { Pallid Harrier Circus } \\
\text { macrourus }\end{array}$ & - & $\operatorname{tr}$ & - & 4 & - & - & - & - & - & - & 4 \\
\hline $\begin{array}{l}\text { Steppe Buzzard Buteo } \\
\text { vulpinus }\end{array}$ & - & mig & 2 & - & - & - & - & - & - & 1 & 3 \\
\hline $\begin{array}{l}\text { Jackal Buzzard Buteo } \\
\text { rufofuscus }\end{array}$ & - & - & 4 & - & 1 & 1 & 1 & - & - & - & 7 \\
\hline \multicolumn{12}{|l|}{ Falconidae } \\
\hline $\begin{array}{l}\text { Amur Falcon Falco } \\
\text { amurensis }\end{array}$ & - & mig & 3 & 83 & - & - & - & - & - & - & 86 \\
\hline \multicolumn{12}{|l|}{ Threskiornithidae } \\
\hline Hadeda Ibis Bostrychia & - & - & - & - & - & - & - & 0 & 0 & 1 & 1 \\
\hline
\end{tabular}




\begin{tabular}{|c|c|c|c|c|c|c|c|c|c|c|c|}
\hline Species & Nectar & Status & Feb & Mar & May & Jun & Jul & Aug & Sep & Oct & Total \\
\hline hagedash & & & & & & & & & & & \\
\hline \multicolumn{12}{|l|}{ Malaconotidae } \\
\hline Brubru Nilaus afer & - & - & - & 0 & 0 & 0 & - & 0 & 0 & 1 & 1 \\
\hline $\begin{array}{l}\text { Brown-crowned Tchagra } \\
\text { Tchagra australis }\end{array}$ & s & - & 10 & 8 & 3 & 1 & 6 & 1 & 12 & 3 & 44 \\
\hline $\begin{array}{l}\text { Bokmakierie Telophorus } \\
\text { zeylonus }\end{array}$ & - & - & 0 & 0 & 4 & 1 & 2 & 1 & 5 & 4 & 17 \\
\hline $\begin{array}{l}\text { Chinspot Batis Batis } \\
\text { molitor }\end{array}$ & - & - & - & - & 1 & 0 & 0 & 0 & 0 & 0 & 1 \\
\hline \multicolumn{12}{|l|}{ Corvidae } \\
\hline Pied Crow Corvus albus & 2 & - & - & - & - & - & - & 5 & 0 & 1 & 6 \\
\hline \multicolumn{12}{|l|}{ Laniidae } \\
\hline $\begin{array}{l}\text { Common Fiscal Lanius } \\
\text { collaris }\end{array}$ & $\mathrm{o}$ & - & - & 1 & 0 & 2 & 1 & 3 & 4 & 5 & 16 \\
\hline \multicolumn{12}{|l|}{ Paridae } \\
\hline $\begin{array}{l}\text { Ashy Tit Parus } \\
\text { cinerascens }\end{array}$ & - & - & 5 & 1 & 4 & 3 & 6 & 1 & 3 & 4 & 27 \\
\hline \multicolumn{12}{|l|}{ Hirudinidae } \\
\hline $\begin{array}{l}\text { Barn Swallow Hirundo } \\
\text { rustica }\end{array}$ & - & mig & 143 & 92 & - & - & - & - & - & 21 & 256 \\
\hline $\begin{array}{l}\text { Greater Striped Swallow } \\
\text { Hirundo cucullata }\end{array}$ & - & mig & 5 & - & - & - & - & - & 15 & 29 & 49 \\
\hline \multicolumn{12}{|l|}{ Pycnonotidae } \\
\hline $\begin{array}{l}\text { African Red-eyed Bulbul } \\
\text { Pycnonotus nigricans }\end{array}$ & $\mathrm{t}, \mathrm{p}, 2$ & - & 51 & 73 & 87 & 50 & 59 & 403 & 65 & 96 & 884 \\
\hline \multicolumn{12}{|l|}{ Sylviidae } \\
\hline $\begin{array}{l}\text { Fairy Flycatcher } \\
\text { Stenostira scita }^{\text {a }}\end{array}$ & - & mig & - & - & - & - & - & 2 & - & - & 2 \\
\hline $\begin{array}{l}\text { Cape Grassbird } \\
\text { Sphenoeacus afer }\end{array}$ & $\mathrm{s}$ & - & - & - & - & - & - & - & - & - & - \\
\hline $\begin{array}{l}\text { Long-billed Crombec } \\
\text { Sylvietta rufescens }\end{array}$ & $\mathrm{s}, 1$ & - & 0 & - & - & - & - & - & 1 & 0 & 1 \\
\hline $\begin{array}{l}\text { Willow Warbler } \\
\text { Phylloscopus trochilus }\end{array}$ & - & mig & - & 2 & - & - & - & - & - & - & 2 \\
\hline $\begin{array}{l}\text { Chestnut-vented Tit- } \\
\text { Babbler Parisoma } \\
\text { subcaeruleum }\end{array}$ & $\mathrm{t}, \mathrm{p}, 2$ & - & 3 & 6 & 1 & 6 & 3 & 14 & 7 & 8 & 48 \\
\hline
\end{tabular}


Zosteropidae

Cape White-eye

Zosterops capensis

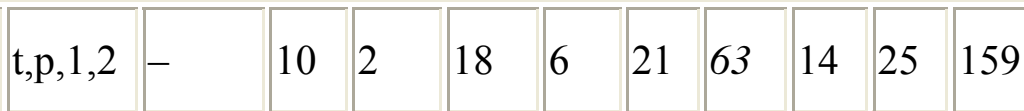

Cisticolidae

\begin{tabular}{|c|c|c|c|c|c|c|c|c|c|c|c|}
\hline $\begin{array}{l}\text { Rattling Cisticola } \\
\text { Cisticola chiniana }\end{array}$ & 0,1 & - & 7 & 9 & 2 & 1 & - & - & 4 & 1 & 24 \\
\hline $\begin{array}{l}\text { Neddicky Cisticola } \\
\text { fulvicapilla }\end{array}$ & $\mathrm{s}, 1$ & - & - & - & 5 & 6 & 3 & 4 & 4 & 8 & 30 \\
\hline $\begin{array}{l}\text { Black-chested Prinia } \\
\text { Prinia flavicans }\end{array}$ & $\mathrm{t}, \mathrm{p}$ & - & 23 & 22 & 17 & 6 & 9 & 19 & 17 & 8 & 121 \\
\hline $\begin{array}{l}\text { Bar-throated Apalis } \\
\text { Apalis thoracica }\end{array}$ & $\mathrm{t}, \mathrm{p}$ & - & 0 & 2 & 5 & 1 & 2 & 6 & 2 & 0 & 18 \\
\hline \multicolumn{12}{|l|}{ Muscicapidae } \\
\hline $\begin{array}{l}\text { Cape Rock-Thrush } \\
\text { Monticola rupestris }\end{array}$ & $\mathrm{t}$ & - & 4 & - & - & - & 1 & 2 & 4 & 0 & 11 \\
\hline $\begin{array}{l}\text { Karoo Thrush Turdus } \\
\text { smithi }\end{array}$ & - & - & 1 & - & - & - & - & - & - & 0 & 0 \\
\hline $\begin{array}{l}\text { Marico Flycatcher } \\
\text { Bradornis mariquensis }\end{array}$ & - & - & - & 1 & - & - & - & - & - & - & 1 \\
\hline $\begin{array}{l}\text { Fiscal Flycatcher Sigelus } \\
\text { silens }\end{array}$ & $\mathrm{t}, \mathrm{p}, 1,2$ & - & 27 & 74 & 59 & 29 & 32 & 93 & 68 & 71 & 453 \\
\hline $\begin{array}{l}\text { Cape Robin-Chat } \\
\text { Cossypha caffra }\end{array}$ & tp & - & 4 & 16 & 5 & 7 & 6 & 6 & 5 & 18 & 67 \\
\hline $\begin{array}{l}\text { Kalahari Scrub-Robin } \\
\text { Cercotrichas paena }\end{array}$ & - & - & - & - & 1 & - & 1 & - & - & - & 2 \\
\hline $\begin{array}{l}\text { Familiar Chat Cercomela } \\
\text { familiaris }\end{array}$ & - & - & - & 1 & 2 & - & - & - & 1 & - & 4 \\
\hline \multicolumn{12}{|l|}{ Sturnidae } \\
\hline $\begin{array}{l}\text { Red-winged Starling } \\
\text { Onychognathus morio }\end{array}$ & 1,2 & - & - & - & - & - & - & 2 & - & - & 2 \\
\hline $\begin{array}{l}\text { Cape Glossy Starling } \\
\text { Lamprotornis nitens }\end{array}$ & 0,2 & - & - & - & - & - & - & - & - & - & - \\
\hline $\begin{array}{l}\text { Wattled Starling } \\
\text { Creatophora cinerea }\end{array}$ & $\mathrm{t}, \mathrm{p}$ & - & - & - & - & - & - & 3 & - & - & 3 \\
\hline $\begin{array}{l}\text { Red-billed Oxpecker } \\
\text { Buphagus } \\
\text { erythrorhynchus }\end{array}$ & - & - & - & - & - & - & - & 1 & - & - & 1 \\
\hline Nectariniidae & & & & & & & & & & & \\
\hline
\end{tabular}




\begin{tabular}{|c|c|c|c|c|c|c|c|c|c|c|c|}
\hline Species & Nectar & Status & Feb & Mar & May & Jun & Jul & Aug & Sep & Oct & Total \\
\hline $\begin{array}{l}\text { Malachite Sunbird } \\
\text { Nectarinia famosa }\end{array}$ & $\mathrm{t}$ & - & - & - & - & - & - & 18 & 5 & - & 23 \\
\hline $\begin{array}{l}\text { White-bellied Sunbird } \\
\text { Cinnyris talatala }\end{array}$ & $\mathrm{t}$ & - & - & - & - & - & 3 & 8 & - & 0 & 11 \\
\hline \multicolumn{12}{|l|}{ Ploceidae $^{b}$} \\
\hline $\begin{array}{l}\text { Cape Weaver Ploceus } \\
\text { capensis }\end{array}$ & $\mathrm{t}, \mathrm{p}, 2$ & - & - & - & - & - & 1 & 76 & 38 & 0 & 115 \\
\hline $\begin{array}{l}\text { Southern Masked- } \\
\text { Weaver Ploceus velatus }\end{array}$ & $\mathrm{t}, \mathrm{p}, 1$ & - & 12 & 1 & 33 & 25 & 18 & 55 & 6 & 6 & 156 \\
\hline $\begin{array}{l}\text { Southern Red Bishop } \\
\text { Euplectes orix }\end{array}$ & - & - & 2 & - & - & - & - & - & - & - & 2 \\
\hline $\begin{array}{l}\text { Red-collared Widowbird } \\
\text { Euplectes ardens }\end{array}$ & $\mathrm{t}$ & - & 22 & 2 & 1 & - & - & 3 & - & - & 28 \\
\hline \multicolumn{12}{|l|}{ Estrildidae } \\
\hline $\begin{array}{l}\text { Cut-throat Finch } \\
\text { Amadina fasciata }\end{array}$ & - & - & - & - & - & - & - & 2 & - & - & 2 \\
\hline $\begin{array}{l}\text { Black-faced Waxbill } \\
\text { Estrilda erythronotos }\end{array}$ & $\mathrm{t}, \mathrm{p}$ & - & 5 & 2 & 2 & 21 & 14 & 16 & - & - & 60 \\
\hline $\begin{array}{l}\text { Common Waxbill } \\
\text { Estrilda astrild }\end{array}$ & 2 & - & 4 & - & - & 3 & - & - & - & - & 7 \\
\hline $\begin{array}{l}\text { Violet-eared Waxbill } \\
\text { Granatina granatina }\end{array}$ & s & - & - & 1 & 1 & 8 & - & 2 & 1 & - & 13 \\
\hline $\begin{array}{l}\text { Green-winged Pytilia } \\
\text { Pytilia melba }\end{array}$ & S & - & 8 & 3 & 1 & 10 & 3 & 1 & 0 & 3 & 29 \\
\hline \begin{tabular}{|l|} 
Jameson's Firefinch \\
Lagonosticta rhodopareia
\end{tabular} & s & - & - & - & 4 & 0 & 1 & 1 & - & - & 6 \\
\hline \multicolumn{12}{|l|}{ Viduidae $^{\mathrm{b}}$} \\
\hline $\begin{array}{l}\text { Dusky Indigobird Vidua } \\
\text { funerea }\end{array}$ & - & - & 3 & - & - & - & - & - & - & - & 3 \\
\hline $\begin{array}{l}\text { Pin-tailed Whydah Vidua } \\
\text { macroura }\end{array}$ & - & - & 11 & 17 & 2 & - & - & - & - & - & 30 \\
\hline $\begin{array}{l}\text { Long-tailed Paradise- } \\
\text { Whydah Vidua } \\
\text { paradisaea }\end{array}$ & - & - & 8 & 12 & 2 & - & - & - & - & - & 22 \\
\hline \multicolumn{12}{|l|}{ Passeridae } \\
\hline $\begin{array}{l}\text { Southern Grey-headed } \\
\text { Sparrow Passer diffusus }\end{array}$ & $\mathrm{s}, 2$ & - & 4 & 5 & 10 & 2 & 12 & 4 & 2 & 7 & 46 \\
\hline
\end{tabular}




\begin{tabular}{|c|c|c|c|c|c|c|c|c|c|c|c|}
\hline Species & Nectar & Status & Feb & Mar & May & Jun & Jul & Aug & Sep & Oct & Total \\
\hline $\begin{array}{l}\text { Black-throated Canary } \\
\text { Serinus atrogularis }\end{array}$ & $t$ & - & 22 & 15 & 4 & 3 & 19 & 4 & 2 & 6 & 75 \\
\hline $\begin{array}{l}\text { Yellow Canary Serinus } \\
\text { flaviventris }\end{array}$ & - & - & 5 & 9 & 4 & 2 & - & 4 & 4 & - & 28 \\
\hline $\begin{array}{l}\text { Streaky-headed Seedeater } \\
\text { Serinus gularis }\end{array}$ & $\mathrm{t}, 1,2$ & - & - & 3 & 5 & 1 & 1 & 10 & 13 & 17 & 50 \\
\hline $\begin{array}{l}\text { Cinnamon-breasted } \\
\text { Bunting Emberiza } \\
\text { tahapisi }\end{array}$ & - & - & - & - & - & - & 0 & - & - & - & 0 \\
\hline $\begin{array}{l}\text { Cape Bunting Emberiza } \\
\text { capensis }\end{array}$ & $t$ & - & 15 & 16 & 11 & 13 & 12 & 10 & 17 & 4 & 98 \\
\hline $\begin{array}{l}\text { Golden-breasted Bunting } \\
\text { Emberiza flaviventris }\end{array}$ & _ & - & - & - & - & - & - & 1 & - & - & 1 \\
\hline Total species & 42 & 17 & 48 & 45 & 45 & 39 & 42 & 51 & 44 & 48 & 83 \\
\hline
\end{tabular}

Abundance (total number) of birds indicated, 0 indicates species was heard only. August italicized as peak flowering time. Taxonomy follows Hockey et al. (2005)

${ }^{a}$ Fairy Flycatcher Stenostira scita is recorded as a migrant, but included in calculations since it arrives in the region (aloe forest) during the winter months ${ }^{b}$ Decreases in abundance of certain Ploceidae and Viduidae are likely due to certain species being less conspicuous in non-breeding eclipse plumages during the non-breeding season

Nectar: $t$ feeding on nectar during transects, $s$ pollen recorded on captured birds from swabs of facial area, $p$ pollen observed on facial area of birds in aloe forest, $o$ birds observed feeding on nectar out of transect times, and species known to feed on aloe nectar, 1 Oatley (1964), 2 Oatley and Skead (1972). Birds with pollen visible on the face were not swabbed. Status: tr all birds were observed perched in the aloe forest unless indicated as transients flying over, mig or seasonal migrants

\section{References}

Armstrong DP (1991) Aggressiveness of breeding territorial honeyeaters corresponds to seasonal changes in nectar availability. Behav Ecol Sociobiol 29:103-111

Botes C (2007) Reproductive co-existence among five sympatric single-stemmed aloes in the Gamtoos River Valley, Eastern Cape. MSc Thesis, Nelson Mandela Metropolitan University, Port Elizabeth 
Brown ED, Hopkins MJG (1996) How New Guinea rainforest flower resources vary in time and space: implications for nectarivorous birds. Aust J Ecol 21:363-378

Collins BG, Newland C (1986) Honeyeater population changes in relation to food availability in the Jarrah forest of Western Australia. Aust J Ecol 11:63-76

Cotton PA (1998) Temporal partitioning of a floral resource by territorial humming birds. Ibis 140:647-653

Cotton PA (2001) The behavior and interactions of birds visiting Erythrina fusca flowers in the Columbian Amazon. Biotropica 33:662-669

Cotton PA (2006) Seasonal resource tracking by Amazonian hummingbirds. Ibis 149:135-142

Craig AJFK (1996) The annual cycle of wing-moult and breeding in the wattled starling Creatophora cinerea. Ibis 138:448-454

Craig AJFK, Hulley PE (1994) Sunbird movements: a review with possible models. Ostrich 65:106-110

Craig AJFK, Simon CA (1991) Sunbird and sugarbird seasons. Safring News 20:9-12

De Swardt DH (1991) The seasonal movements of Gurney's Sugarbird Promerops gurneyi in the Lydenburg area, Transvaal. Ostrich 62:40-44

De Swardt DH, Louw S (1994) The diet and foraging behaviour of Gurney's Sugarbird Promerops gurneyi. Navorsinge van die Nasionale Museum Bloemfontein 10:245-258

Fleming TH (1992) How do fruit- and nectar-feeding birds and mammals track their food resources? In: Hunter MD, Ohgushi T, Price PW (eds) Effects of resource distribution on animal-plant interactions. Academic, San Diego, pp 355-391

Ford HA (1981) Territorial behaviour in an Australian nectar-feeding bird. Aust Ecol $6: 131-134$

Franklin DC (1999) Opportunistic nectarivory: an annual dry season phenomenon among birds in monsoonal northern Australia. Emu 99:135-141

Franklin DC, Noske RA (1999) Birds and nectar in a monsoonal woodland: correlations at three spatio-temporal scales. Emu 99:15-28 
Fraser MW (1997) Malachite Sunbird Nectarinia famosa. In: Harrison JA, Allan DG, Underhill LG, Herremans M, Tree AJ, Parker V and Brown CJ (eds) The atlas of Southern African birds vol 2: Passerines. BirdLife South Africa, Johannesburg, pp 488490

Fraser MW, McMahon L (1992) Habitat change by Cape Sugarbirds and Orangebreasted Sunbirds in an apparent response to fire in old mountain fynbos. Safring News 21:51-54

Fraser MW, McMahon L, Underhill LG, Underhill GD, Rebelo AG (1989) Nectarivore ringing in the southwestern Cape. Safring News 18:3-18

Frost SK, Frost PGH (1980) Territoriality and changes in resource use by sunbirds at Leonotis leonurus (Labiatae). Oecologia 45:109-116

Gill BG, Wolf LL (1975) Economics of feeding territoriality in the Golden-Winged Sunbird. Ecology 56:333-345

Glen HF, Hardy DS (2000) Fascicle 1: Aloaceae (First part): Aloe. In: Germishuizen G (ed) Flora of southern Africa, vol 5, part 1. National Botanical Institute, Pretoria

Gryj E, Martinez del Rio C, Baker E (1990) Avian pollination and nectar use in Combretum fructicosum (Loefl). Biotropica 22:266-271

Harrison JA, Allan DG, Underhill LG, Herremans M, Tree AJ, Parker V, Brown CJ (eds) (1997) The atlas of Southern African birds vol 2: Passerines. BirdLife South Africa, Johannesburg

Hockey PAR, Dean WRJ, Ryan PG (eds) (2005) Roberts'-Birds of Southern Africa, 7th edn. The Trustees of the John Voelcker Bird Book Fund, Cape Town

Hoffman MT (1988) The pollination ecology of Aloe ferox Mill. S Afr J Bot 54:345-350

Jeppe B (1969) South African Aloes. Purnell, Cape Town

Maclean GL (1990) Ornithology for Africa. University of Natal Press, Pietermaritzburg

Maclean GL (1993) Roberts' birds of southern Africa. John Voelcker Bird Book Fund. Cape Town 
Mendoça LB, dos Anjos L (2006) Feeding behavior of hummingbirds and perching birds on Erythrina speciosa Andrews (Fabaceae) in an urban area, Londrina, Paraná, Brazil. Rev Bras Zool 23:42-49

Oatley TB (1964) The probing of Aloe flowers by birds. Lammergeyer 3:2-8

Oatley TB, Skead DM (1972) Nectar-feeding by South African birds. Lammergeyer 15:68-69

Ornelas JF, Ordano M, Hernández A, López JC, Mendoza L, Perroni Y (2002) Nectar oasis produced by Agave marmorata Roezl. (Agavaceae) lead to spatial and temporal segregation among nectarivores in the Tehuacán Valley, México. J Arid Environ 52(1):37-51

Paton D C (1986) Evolution of bird pollination in Australia. In: Ford HA, Paton DC (eds) The dynamic partnership: birds and plants in Southern Australia. The Flora and Fauna of South Australia Handbooks Committee, Adelaide, pp 32-41

Peterson RT (and the Editors of Life) (1968) The Birds. Time, Holland

Raju AJS, Rao SP (2004) Passerine bird pollination and fruiting behaviour in a dry season blooming tree species Erythrina suberosa Roxb (Fabaceae) in the Eastern Ghats forests India. Ornithol Sci 3:139-144

Ramsey MW (1989) The seasonal abundance and foraging behaviour of honeyeaters and their potential role in the pollination of Banksia menziesii. Aust J Ecol 14:33-40

Reynolds GW (1969) The aloes of South Africa. Balkema, Cape Town

Skead CJ (1967) Sunbirds of Southern Africa. Balkema, Cape Town

Steiner KM (1979) Passerine pollination of Erythrina megistophylla Diels (Fabaceae). Ann Mo Bot Gard 66:490-502

Stiles FG (1981) Geographical aspects of bird-flower coevolution, with particular reference to Central America. Ann Mo Bot Gard 68:323-351

Symes CT, Downs CT, McLean S (2001) Seasonal occurrence of the Malachite Sunbird Nectarinia famosa and Gurney's Sugarbird Promerops gurneyi in KwaZulu-Natal South Africa. Ostrich 72:45-49 
Timewell CAR, MacNally R (2004) Diurnal foraging-mode shifts and food availability in nectarivore assemblages during winter. Aust Ecol 29:264-277

Tree AJ (1990) Notes on sunbird movements and nectar sources in Zimbabwe. Honeyguide 36:171-182

van Wyk B-E, Smith G (2003) Guide to the Aloes of southern Africa. Briza, Pretoria

Woinarski JCZ, Tidemann SC (1991) The bird fauna of a deciduous woodland in the wetdry tropics of Northern Australia. Wildl Res 19:479-500 